\begin{tabular}{|c|c|c|c|}
\hline celeuma & número 4 | maio 2014 & | cartas & 110 \\
\hline
\end{tabular}

\title{
'MAL SEI O QUE DIZER'
}

6 de março de 1917 Seefeldstrasse 73, Zurique VIII

Prezado Senhor (ou Senhora): os senhores Black, Monro, Saw\&Co. me escreveram em 22 de fevereiro informando que foram instruídos por você a me enviar a cada dia $1^{\circ}$ dos meses de maio, agosto, setembro e fevereiro cheques de 50 libras, perfazendo um total de 200 libras. Eles acrescentam que você é um admirador da minha obra e que deseja permanecer anônimo[1]. Antes de mais nada, peço que perdoe a minha demora em lhe responder. Desde 4 de fevereiro estou de cama por causa de uma enfermidade dolorosa e de risco nos olhos (irite reumática). Como é a quinta vez que sofro disso, e agravado por uma sinequia, foi quase impossível para mim escrever até o dia de hoje.

Estou profundamente tocado por sua generosidade. Mal sei o que lhe dizer. Deu-me grande encorajamento e, vindo num momento como o presente, alivia-me de muitas preocupações. Permita-me expressar a minha mais sincera gratidão tanto pela munificência do seu donativo quanto pela gentileza de sua proposição. Espero que o futuro possa justificar em parte um ato de tanta nobreza e consideração.

Gostaria de retribuir com algo singelo, por isso estou escrevendo aos editores dos meu livros e solicitando que me enviem exemplares os quais eu peço que você aceite com uma dedicatória minha.

Tão logo eu esteja curado continuarei escrevendo um romance no qual estou trabalhando Ulisses. Escrevi também uma peça Exilados e se for publicada neste ano, a enviarei a você.

Novamente peço que aceite o meu mais profundo agradecimento e esteja certa de toda a minha gratidão e sou sinceramente seu

JAMES JOYCE

[1] A senhorita Weaver revelou sua identidade como benfeitora somente em julho de 1919 . 